\title{
PENILAIAN HASIL BELAJAR PESERTA DIDIK PADA SMP TERBUKA BERBASIS TIK
}

Oleh: Ika Kurniawati *)

\section{Abstrak}

Demi meningkatkan layanan serta kualitas pembelajaran di SMP Terbuka, baru-baru ini pemerintah telah meresmikan SMP Terbuka berbasis Teknologi Informasi dan Komunikasi (TIK). Diharapkan dengan program ini dapat ditingkatkan kualitas pembelajaran SMP Terbuka terutama dalam kemandirian peserta didik sehingga mereka memiliki daya saing, inovasi dan kreativitas yang tinggi. SMP Terbuka berbasis TIK dirintis di 3 lokasi, yaitu di: (1) SMP Terbuka Negeri 01 Malang, Jawa Timur yang menginduk pada SMPN 2 Malang, (2) SMP Terbuka Kandanghaur, IndramayuJawa Barat yang menginduk pada SMP Negeri 1 Kandanghaur, dan (3) SMP Terbuka Tanjung Priok, Jakarta yang menginduk pada SMPN 55 Jakarta Utara. Kegiatan pembelajaran berbasis TIK di SMP Terbuka dilaksanakan, baik secara online maupun offline yang dilengkapi dengan berbagai sumber belajar yang didukung oleh kegiatan pembelajaran mandiri dan tatap muka. Penilaian hasil belajar peserta didik juga dilakukan secara online. Penilaian hasil belajar peserta didik yang dilakukan secara online antara lain: Tes Akhir Kegiatan (TAK), Tes Akhir Modul (TAM), Tes Akhir Unit (TAU), dan Tes Akhir Semester. Untuk Ujian Sekolah dan Ujian Nasional tetap dilakukan secara manual dengan mengikuti jadwal SMP Reguler.

Kata kunci: Penilaian, Hasil Belajar Peserta didik, SMP Terbuka, Teknologi Informasi dan Komunikasi

\section{A. PENDAHULUAN}

\section{Latar Belakang Masalah}

SMP Terbuka merupakan lembaga pendidikan formal yang tidak berdiri sendiri tetapi merupakan bagian dari SMP Induk yang dalam menyelenggarakan pendidikannya menggunakan metode belajar mandiri. SMP Terbuka diselenggarakan secara khusus untuk melayani tamatan SD/MI yang karena kondisi sosial ekonomi, kondisi geografis, keterpencilan lokasi, hambatan transportasi, hambatan waktu karena harus bekerja membantu orang tua, atau bekerja sendiri mencari nafkah untuk memenuhi kebutuhan hidupnya. (Direktorat PSMP, 2009).

Dalam penyelenggaraannya, SMP Terbuka telah banyak membantu peserta didik usia sekolah menyelesaikan pendidikannya. SMP Terbuka turut membantu anggota masyarakat usia sekolah yang tidak mampu menempuh SMP reguler karena memiliki beberapa kendala seperti dijelaskan diatas.

*) Ika Kurniawati, M.Pd., adalah staf Bidang Teknologi Informasi pada Pusat Teknologi Informasi dan Komunikasi Pendidikan-Kementerian Pendidikan Nasional (Pustekkom-Kemendiknas). 
Sehingga SMP Terbuka ikut menyukseskan program pemerintah untuk pemerataan akses dan layanan pendidikan.

Demi meningkatkan layanan serta kualitas pembelajaran di SMP Terbuka, baru-baru ini pemerintah telah meresmikan SMP Terbuka berbasis TIK. Diharapkan dengan program ini dapat meningkatkan kualitas pembelajaran SMP Terbuka terutama dalam meningkatkan kemandirian peserta didik sehingga mereka memiliki daya saing, inovasi dan kreativitas yang tinggi. Sekolah rintisan SMP Terbuka berbasis TIK ini meliputi 3 SMP Terbuka, antara lain sebagai berikut.

a. SMP Terbuka Negeri 01 Malang Jawa Timur yang menginduk pada SMPN 2 Malang.

b. SMP Terbuka Kandanghaur Indramayu Jawa Barat yang menginduk pada SMP Negeri 1 Kandanghaur.

c. SMP Terbuka Tanjung Priok Jakarta yang menginduk pada SMPN 55 Jakarta Utara

(Direktorat PSMP, 2009)

Kegiatan pembelajaran berbasis TIK di SMP Terbuka dilaksanakan secara online dan offline dilengkapi dengan berbagai sumber belajar yang didukung oleh kegiatan pembelajaran mandiri dan kegiatan pembelajaran tatap muka.

Untuk mengetahui apakah peserta didik pada SMP Terbuka berbasis TIK telah memenuhi kompetensi yang telah ditentukan, maka perlu dilakukan penilaian terhadap peserta didik. Penilaian hasil belajar merupakan kegiatan pengendalian, penjaminan, dan penetapan mutu pendidikan terhadap berbagai komponen pendidikan sebagai bentuk pertanggungjawaban penyelenggaraan pendidikan.

Penilaian hasil belajar peserta didik pada SMP Terbuka yang menjadi perintis Pengembangan Program Pembelajaran Berbasis TIK seperti dijelaskan dalam Naskah Akademik Pengembangan Program Pembelajaran Berbasis TIK pada SMP Terbuka (Direktorat PSMP, 2009) terdiri atas:

a. Penilaian hasil belajar oleh diri peserta didik sendiri (Self Assesment).

b. Penilaian hasil belajar oleh pendidik (Teacher Assesment).

c. Penilaian hasil belajar oleh satuan pendidikan (Institusional Assesment / School Examination).

d. Penilaian hasil belajar oleh pemerintah (National Assessment / National Examination)

Penilaian hasil belajar oleh diri peserta didik sendiri pada SMP Terbuka berbasis TIK lebih dikenal dengan Tes Akhir Kegiatan (TAK). Penilaian hasil belajar oleh pendidik dikenal dengan Tes Akhir Modul (TAM), Tes Akhir Unit (TAU) dan Tes Akhir Semester (TAS). Sedangkan penilaian hasil belajar oleh satuan pendidikan dikenal dengan ujian sekolah. Penilaian hasil belajar oleh pemerintah dikenal dengan ujian nasional.

Beberapa jenis penilaian hasil belajar pada peserta didik SMP Terbuka berbasis TIK dilakukan secara online, yaitu Tes Akhir Modul (TAM), Tes Akhir Unit (TAU), dan Tes Akhir Semester. Sementara untuk pelaksanaan ujian sekolah dan ujian nasional dilaksanakan secara manual mengikuti ujian yang ditempuh oleh peserta didik SMP reguler.

Yang menjadi pertimbangan dilakukannya tes secara online antara lain:

a. Penyingkatan waktu untuk skoring/ penilaian bagi penguji. Pekerjaan yang paling membutuhkan waktu dan menjenuhkan bagi penguji adalah pada saat melakukan penskoran/ penilaian terhadap hasil tes peserta didik. Penguji harus melihat dan menilai setiap jawaban dalam setiap soal untuk seluruh peserta tes. Tentu pekerjaan ini cukup menyita waktu penguji di SMP Terbuka. Padahal penguji dalam hal ini Guru Bina waktunya harus berbagi dengan peserta didik di SMP reguler. Dengan tes online ini cukup meringankan 
beban kerja guru bina.

b. Memudahkan manajemen dan database hasil tes. Tes online memudahkan dalam melihat dan memanajemen hasil tes. Guru Bina dapat secara langsung melihat dan manganalisis hasil tes. Disamping itu, Guru Bina dapat juga melihat tampilan grafik statistik nilai rata-rata kelas, nilai tertinggi atau terendah, dan lain-lain.

c. Paperless. Dengan pelaksanaan tes online dapat menghemat pemakaian kertas.(http://ptinvosasystems. indonetwork.co.id/67162/sistem-testonline.htm)

Di samping beberapa kemudahan yang ditawarkan dengan penerapan tes online, ada beberapa persyaratan yang harus dipenuhi antara lain kesiapan infrastruktur, perangkat keras maupun perangkat lunak, serta sumber daya manusia.

Berkaitan dengan infrastruktur antara lain diperlukan ruangan yang memadai, listrik yang stabil, serta akses internet yang lancar. Perangkat keras yang diperlukan antara lain komputer yang terhubung dengan jaringan, serta aplikasi tes online itu sendiri berkaitan dengan perangkat lunak. Ketrampilan sumber daya manusia yang diperlukan antara lain kemampuan mengoperasikan komputer, baik guru bina maupun peserta didik.

\section{Tujuan}

Tujuan penulisan artikel ini untuk berbagi informasi tentang penilaian hasil belajar peserta didik, jenis tes dan ujian, serta strategi pelaksanaan tes online pada perintisan SMP Terbuka berbasis TIK.

\section{B. KAJIAN LITERATUR}

\section{Penilaian Hasil Belajar Pada Peserta didik SMP Terbuka Berbasis TIK}

\section{a. Kebijakan Penilaian Hasil Belajar di SMP}

Berdasarkan Permendiknas No. 20 Tahun 2007 tentang Standar Penilaian Pendidikan menyebutkan bahwa penilaian pendidikan pada jenjang pendidikan dasar dan menengah terdiri atas penilaian hasil belajar oleh pendidik, oleh satuan pendidikan, dan oleh pemerintah.

Penilaian pendidikan merupakan proses pengumpulan dan pengolahan informasi untuk menentukan pencapaian hasil belajar peserta didik. Penilaian hasil belajar peserta didik dilaksanakan berdasarkan standar penilaian pendidikan yang dilakukan secara nasional. Standar penilaian pendidikan merupakan standar nasional pendidikan yang berkaitan dengan mekanisme, prosedur, dan instrumen penilaian hasil belajar peserta didik. Penilaian dapat berupa ulangan dan atau ujian.

Ulangan adalah proses yang dilakukan untuk mengukur pencapaian kompetensi peserta didik secara berkelanjutan dalam proses pembelajaran, memantau kemajuan, melakukan perbaikan pembelajaran, dan menentukan keberhasilan belajar peserta didik. Ulangan yang diberikan dapat berupa ulangan harian, ulangan tengah semester, ulangan akhir semester, dan ulangan kenaikan kelas. Sedangkan ujian itu sendiri meliputi ujian nasional dan ujian sekolah/madrasah.

Seperti telah dijelaskan sebelumnya, bahwa penilaian pendidikan pada jenjang pendidikan dasar dan menengah terdiri atas penilaian hasil belajar oleh pendidik, satuan 
pendidikan, dan pemerintah. Penilaian hasil belajar yang dilakukan oleh pendidik antara lain meliputi: ulangan harian, ulangan tengah semester, ulangan akhir semester, dan ulangan kenaikan kelas. Penilaian hasil belajar yang dilakukan satuan pendidikan lebih dikenal dengan ujian sekolah/madrasah. Sedangkan penilaian hasil belajar yang dilakukan oleh pemerintah dikenal dengan ujian nasional. (Depdiknas, 2007)

Ulangan harian adalah kegiatan yang dilakukan secara periodik untuk mengukur pencapaian kompetensi peserta didik setelah menyelesaikan satu Kompetensi Dasar (KD) atau lebih. Ulangan tengah semester adalah kegiatan yang dilakukan oleh pendidik untuk mengukur pencapaian kompetensi peserta didik setelah melaksanan 8-9 minggu kegiatan pembelajaran. Cakupan ulangan meliputi seluruh indikator yang merepresentasikan seluruh KD pada periode tersebut.

Ulangan akhir semester adalah kegiatan yang dilakukan oleh pendidik untuk mengukur pencapaian kompetensi peserta didik di akhir semester. Cakupan ulangan akhir semester meliputi seluruh indikator yang merepresentasikan semua KD pada semester tersebut. Ulangan kenaikan kelas adalah kegiatan yang dilakukan oleh pendidik di akhir semester genap untuk mengukur pencapaian kompetensi peserta didik di akhir semester genap pada satuan pendidikan yang menggunkan sistem paket. Cakupan ulangan meliputi seluruh indikator yang merepresentasikan KD pada semester tersebut.

Ujian sekolah/madrasah merupakan proses pengukuran pencapaian kompetensi peserta didik oleh satuan pendidikan sebagai pengakuan atas prestasi hasil belajar. Merupakan salah satu persyaratan kelulusan dari satuan pendidikan. Mata pelajaran yang diujikan mencakup kelompok mata pelajaran yang tidak diujikan dalam Ujian Nasional, meliputi aspek kognitif dan atau psikomotor.

Ujian Nasional (UN) merupakan proses pengukuran pencapaian kompetensi peserta didik untuk mencapai standar penilaian pendidikan yang diselenggarakan oleh pemerintah. Seperti halnya ujian sekolah, Ujian Nasional merupakan salah satu persyaratan kelulusan dari satuan pendidikan. Mata pelajaran yang diujikan adalah Bahasa Indonesia, Bahasa Inggris, Matematika, dan IImu Pengetahuan Alam.

\section{b. Penilaian Hasil Belajar Peserta didik Pada SMP Terbuka Berbasis TIK}

Penilaian hasil belajar pada peserta didik SMP Terbuka khususnya yang berbasis TIK mengikuti semua jenis dan bentuk penilaian, baik yang dilakukan oleh pendidik, satuan pendidikan, maupun oleh pemerintah.

Dalam Permendiknas No. 20 Tahun 2007 juga dijelaskan tentang teknik dan instrumen penilaian bahwa penilaian hasil belajar oleh peserta didik menggunakan berbagai teknik penilaian berupa tes, observasi, penugasan perseorangan atau kelompok, dan bentuk lain yang sesuai dengan karakteristik kompetensi dan tingkat perkembangan peserta didik. Teknik tes berupa tes tertulis, lisan, dan praktik atau tes kinerja. Teknik observasi atau pengamatan dilakukan selama pembelajaran berlangsung dan atau di luar kegiatan pembelajaran. Teknik penugasan baik perseorangan maupun kelompok dapat berbentuk tugas rumah dan atau proyek.

Jenis dan bentuk tes pada program SMPT berbasis TIK dapat berbentuk 
tes tertulis. Tes tertulis dapat berupa (1) tes uraian (essay test), baik tes uraian bebas maupun tes uraian terikat dan (2) tes objektif (pilihan) berupa butir benar salah, pilihan berganda, isian melengkapi, jawaban singkat, dan menjodohkan. Tes pada program SMPT berbasis TIK dilakukan secara online. Proses pengerjaan tes maupun hasil dilakukan secara online. Tes tertulis seperti dikemukakan di atas memungkinkan semuanya dilakukan secara online.

Tes formatif yang dilakukan pada SMPT berbasis TIK (SMPT online) yaitu Tes Akhir Modul (TAM). Test Akhir Unit (TAU) disebut juga Tes Sub-sumatif. Sedangkan tes akhir semester (TAS) yang dilakukan pada tiap akhir semester merupakan tes sumatif. TAK, TAM serta TAU dapat juga dikategorikan sebagai entering behavior test untuk melanjutkan ke kegiatan belajar, modul, atau unit berikutnya. Lebih jelasnya dapat dilihat pada diagram berikut.

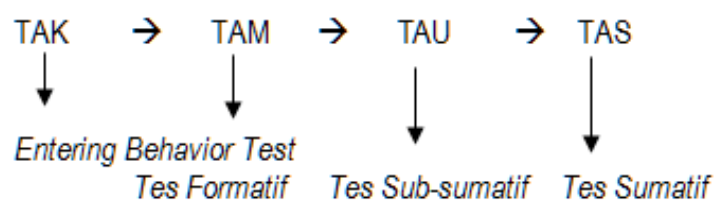

Baik TAK, TAM, TAU maupun TAS merupakan post test karena dilakukan setelah peserta didik menyelesaikan suatu kegiatan belajar atau modul. Pretest dapat dilakukan sebelum peserta didik mulai mempelajari suatu kegiatan belajar yang dapat berupa kuis/pertanyaan singkat untuk mengetahui tingkat kesiapan peserta didik mempelajari materi dalam kegiatan belajar, (Mudjijo, 1995).

Sebagai dasar pertimbangan untuk menentukan penguasaan peserta didik terhadap indikator maupun kompetensi bentuknya tidak hanya berbentuk tes tetapi juga non tes,
(Thorndike, 1977). Non tes antara lain dapat berbentuk karangan, karya ilmiah, ataupun portofolio peserta didik. Adapun proses pengerjaannya dapat dilakukan secara online termasuk pengiriman hasilnya kepada Guru Bina dan demikian juga dengan hasil penilaiannya kepada peserta didik dengan memanfaatkan layanan email atau lainnya. Untuk penafsiran hasilnya, Guru Bina memiliki peran utama karena penilaian non tes belum bisa dilakukan otomatis oleh sistem.

Pengerjaan tes online pada SMPT berbasis TIK yaitu dengan terlebih dahulu mengakses alamat situs portal SMPT di http://smpt.dit-plp.go.id Berikut merupakan jenis tes yang harus diikuti oleh peserta didik SMPT berbasis TIK.

1) Tes Akhir Kegiatan (TAK), adalah tes yang dilaksanakan pada setiap akhir kegiatan belajar di dalam modul yang dikerjakan secara mandiri dengan standar ketuntasan $75 \%$. Setelah selesai mempelajari satu kegiatan belajar tertentu, peserta didik mengerjakan soal-soal atau tugas-tugas yang tersedia secara manual. Setelah selesai, peserta didik dapat mengoreksi sendiri jawabannya (merupakan selfassessment) dan mencocokkannya dengan kunci jawaban yang tersedia di bagian akhir modul. Tes Akhir Kegiatan disebut juga Tugas Akhir Kegiatan (TAK). Bila hasilnya belum mencapai standar ketuntasan, maka peserta didik yang bersangkutan mempelajari lagi materi kegiatan sampai dia memenuhi standar ketuntasan 75\%. Hasil Tes Akhir Kegiatan ini selanjutnya dilaporkan secara online.

2) Tes Akhir Modul (TAM) disebut juga Tes Formatif atau ulangan harian, adalah tes yang dilaksanakan setiap kali peserta 
didik menyelesaikan satu modul tertentu dengan standar ketuntasan 75\%. Pelaksanaan tes akhir modul menjadi tanggung jawab Guru Bina yang dibantu oleh Guru Pamong sesuai dengan mata pelajaran yang bersangkutan. Tes Akhir Modul dilaksanakan secara online.

3) Tes Akhir Unit (TAU) disebut juga Tes Sub-sumatif atau ulangan harian adalah tes yang dilaksanakan setelah peserta didik memepelajari beberapa nomor modul dalam satu satuan unit dengan standar ketuntasan (SKBM) yang ditentukan oleh masing-masing perintisan SMP Terbuka berbasis TIK. Pelaksanaan Tes Akhir Unit menjadi tanggung jawab Guru Bina. Tes Akhir Unit dilaksanakan secara online.

4) Tes Akhir Semester (TAS) disebut juga Tes Sumatif atau ulangan umum merupakan tes yang dilaksanakan pada setiap akhir semester untuk mengukur hasil belajar selama satu semester dengan standar ketuntasan (SKBM) yang ditentukan oleh masing-masing perintisan SMP Terbuka berbasis TIK. Pelaksanaan Tes Akhir Semester juga menjadi tanggung jawab Guru Bina dan dilaksanakan secara online.

Untuk soal tes yang dilaksanakan secara online yaitu Tes Akhir Modul, Tes Akhir Unit, dan Tes Akhir Semester telah disusun oleh pihak Direktorat Pembinaan SMP dengan melibatkan guru sesuai mata pelajaran masingmasing. Sementara ini tes online yang telah dikembangkan baru meliputi mata pelajaran yang termasuk ujian nasional.

5) Ujian
Selain tes yang dilakukan secara online, peserta didik SMP Terbuka berbasis TIK juga wajib mengikuti ujian, yaitu Ujian Sekolah, dan Ujian Nasional. Ujian Sekolah adalah ujian yang dilaksanakan setelah berakhirnya program belajar selama 3 tahun di SMP Terbuka untuk semua mata pelajaran, kecuali mata pelajaran yang diujikan secara nasional. Pembuatan soal ujian sekolah menjadi tanggung jawab Musyawarah Guru Mata Pelajaran (MGMP) tingkat Kabupaten/Kota setempat. Untuk pelaksanaannya menjadi tanggung jawab masing-masing sekolah. Ujian sekolah dilaksanakan secara manual.

Ujian Nasional adalah ujian yang diselenggarakan bagi peserta didik SMP Terbuka kelas IX pada akhir program belajar selama 3 tahun di SMP Terbuka. Mata Pelajaran yang diujikan secara nasional ditentukan oleh Badan Standar Nasional Pendidikan (BSNP). Hasil ujian nasional digunakan sebagai salah satu bahan untuk memutuskan apakah seorang peserta didik telah dianggap memenuhi persyaratan akademis untuk lulus. Ketentuan penyelenggaraan ujian nasional disesuaikan dengan peraturan yang berlaku. Ujian Nasional dilaksanakan secara manual mengikuti ujian yang ditempuh oleh peserta didik SMP Reguler.

\section{Strategi Pelaksanaan Penilaian}

Dalam pengembangan tes hasil belajar khususnya pada peserta didik SMPT berbasis TIK telah dikembangkan oleh pusat terutama untuk Tes Akhir Kegiatan (TAK), Tes Akhir Modul (TAM), Tes Akhir Unit (TAU), dan TAS (Tes Akhir Semester). Tes yang telah dikembangkan tersebut juga telah melalui tahapan uji coba, sehingga didapatkan butir-butir soal 
yang valid dan reliabel. Guru Bina bisa terlibat dalam pengembangan penilaian hasil belajar yang bentuknya non tes seperti karangan, catatan peserta didik, atau tugas maupun karya ilmiah yang dibuat oleh peserta didik.

TAK, TAM, TAU, dan TAS karena penyelenggaraannya dilakukan secara online, maka guru (Guru Bina dan Guru Pamong), peserta didik, maupun pihak pengelola SMPT berbasis TIK harus mengetahui strategi pelaksanaannya, baik sebelum, selama, dan sesudah tes.

\section{a. Strategi sebelum pelaksanaan tes/ ujian}

Dalam penyelenggaraan tes online ini ada beberapa persyaratan yang harus dipenuhi, di antaranya apabila dilakukan di sekolah induk maka sekolah tersebut harus siap baik dari segi SDM maupun infrastruktur. Pada peserta didik sendiri, mereka telah menuntaskan kompetensi yang diharapkan sebelum mereka menjalankan tes. Disamping itu mereka dituntut untuk menguasai TIK, khususnya dalam mengoperasikan komputer.

Hal-hal yang perlu dilakukan sebelum pelaksanaan tes/ujian:

\section{1) Guru Bina}

Tes/ujian online ini dilakukan di Sekolah Induk. Penentuan lokasi ini dengan pertimbangan keterbatasan sarana prasarana maupun SDM apabila dilakukan di luar Sekolah Induk. Beberapa hal yang perlu dilakukan oleh Guru Bina:
a) Mengatur peserta didik yang akan mengikuti tes online baik TAK, TAM, TAU, maupun TAS.
b) Mendokumentasikan hasil tes yang telah dilakukan oleh peserta didik.
c) Menginformasikan kepada peserta didik cakupan materi ataupun indikator dari

masing-masing tes. Misalnya untuk Tes Akhir Kegiatan (TAK) cakupan materinya ataupun indikatornya berasal dari kegiatan belajar yang bersangkutan. Tes Akhir Modul (TAM) cakupan materinya diambil dari modul yang bersangkutan. Dengan demikian peserta didik akan tahu, apabila mereka belum menuntaskan suatu kegiatan belajar ataupun suatu modul, mereka tidak akan bisa mengikuti tes-tes tersebut.

d) Membuat jadwal pelaksanaan tesnya, sehingga seluruh peserta didik SMPT dapat mengikuti tes online ini.

e) Membuat catatan atau rekap tes apa saja yang akan diikuti oleh peserta didik, walaupun data ini sebenarnya sudah terekam secara otomatis oleh sistem. Catatan ini berguna untuk mengingatkan atau memotivasi peserta didik yang belum menuntaskan kompetensi yang seharusnya mereka kuasai.

f) Membantu pengelola dalam menyiapkan tempat baik ruangan, akses maupun infrastruktur lainnya.

2) Peserta didik

Hal-hal yang harus dilakukan oleh peserta didik sebelum mengikuti tes/ujian online ini antara lain:

a) Menentukan tes/ujian yang akan mereka ikuti. Peserta didik dapat membuka rekaman jejak langkah mereka secara online. Jejak langkah kemajuan belajar peserta didik antara lain meliputi informasi tentang: kompetensi atau modul yang telah diselesaikan, diskusi dan tutorial yang diikuti, kuis atau tes yang telah dilakukan, dan latihan atau tugas yang telah dikerjakan. 
b) Mempersiapkan diri, baik fisik maupun mental agar dapat mengerjakan tes dengan lancar.

c) Memperhatikan jadwal pelaksanaan tes sehingga tidak bentrok dengan peserta didik lainnya karena keterbatasan sarana prasarana maupun akses internet.

d) Memiliki kemampuan dalam pengoperasian komputer terutama dalam pengenalan simbol-simbol atau tombol yang harus mereka klik karena kesalahan dalam menekan tombol bisa berakibat fatal dengan kata lain mereka tidak bisa mengikuti tes.

e) Mencoba menu latihan sebelum mengerjakan tes.

3) Pengelola

Pihak pengelola perlu menyiapkan ruangan maupun fasilitas lainnya serta akses internet. Pastikan kondisi listrik di tempat pelaksanaan tes/ujian cukup stabil serta ikut bertanggung jawab terhadap konektivitas akses internet.

\section{b. Strategi pada saat pelaksanaan tes/ ujian}

1) Guru Bina

a) Memastikan pelaksanaan tes sesuai dengan jadwal yang telah disepakati.

b) Memastikan peserta yang akan megikuti tes sesuai dengan jadwal.

c) Memberikan informasi pendahuluan sebelum peserta didik melaksanakan tes, misalnya petunjuk atau tahapan yang harus dilalui peserta didik sebelum menjawab butir-butir soal, dari mulai log in, pengisian user name, dan password, sampai petunjuk pengerjaan tes.

d) Menjamin kelancaran pelaksanaan tes.

2) Peserta didik

a) Memastikan kehadirannya untuk mengikuti tes sesuai jadwal.

b) Sebelum menjalankan tes, memahami terlebih dahulu tahapan yang harus dilalui sebelum menjawab butir-butir pertanyaan, mulai log in, mengisi user name dan password sampai petunjuk pengerjaan tes. Pada saat login jangan sampai salah atau tertukar dalam pengisian user name dan passwordnya, karena hal ini akan berakibat mereka tidak dapat mengerjakan tes atau hasil tes bukan atas nama mereka karena tertukarnya user name dan password dengan peserta didik lainnya.

c) Mengerjakan tes sesuai petunjuk pengerjaannya dan semua butir soal.

d) Setelah mengerjakan tes, memastikan langkah berikutnya yang harus ditempuh tidak terlewat, misalnya harus menekan tombol selesai atau tombol lainnya yang ada dalam aplikasi untuk mengakhiri pengerjaan tes sehingga jawaban peserta didik terekam di sistem.

\section{3) Pengelola}

Pihak pengelola bertanggung jawab terhadap kelancaran pelaksanaan tes, antara lain jangan sampai listrik padam saat pelaksanaan seperti menghubungi pihak PLN sebelum hari pelaksanaan. Di samping itu menjamin stabilnya akses internet dengan cara menghubungi pihak terkait. 
c. Strategi setelah pelaksanaan tes/ ujian

Setelah tes dilakukan, ada beberapa hal yang dilakukan baik oleh Guru Bina, peserta didik, maupun pihak pengelola SMPT online.

1) Guru Bina

a) Setelah peserta didik selesai mengerjakan tes, Guru Bina harus log in ke portal SMPT online untuk merekam hasil tes peserta didik.

b) Dari hasil tes peserta didik, Guru Bina melakukan analisis, sintesis maupun evaluasi untuk menentukan tindak lanjutnya. Berikan feedback terhadap hasil tes peserta didik dengan memanfaatkan layanan email, fasilitas internet lainnya atau bila memungkinkan menggunakan fasilitas handphone. Umpan balik ini sangat bermanfaat untuk mempertahankan atau meningkatkan motivasi belajar peserta didik terkait dengan kemandirian mereka dalam belajar.

c) Membuat catatan pada bagian mana peserta didik banyak yang tidak berhasil menyelesaikan tes, sehingga pada saat tutorial, baik secara synchronous maupun asynchronous, materi tutorial lebih ditekankan pada yang belum banyak dikuasai oleh peserta didik. Peserta didik dianggap belum berhasil apabila belum mencapai nilai sesuai standar ketuntasan (SKBM) yang ditetapkan oleh masing-masing sekolah perintisan SMPT berbasis TIK.

2) Peserta didik

Setelah mengerjakan tes, hasil pekerjaan mereka langsung dapat ditampilkan secara online.
Peserta didik dapat langsung mengetahui apakah mereka telah berhasil menyelesaikan suatu kegiatan belajar atau modul, termasuk tindak lanjut yang harus mereka kerjakan.

a) Memeriksa hasil tes, berhasil atau tidak.

b) Memperhatikan tindak lanjut tes. Apakah harus mempelajari kembali atau dapat melanjutkan ke kegiatan belajar atau modul berikutnya.

c) Membuat catatan pada bagian yang kurang dikuasai. Apabila peserta didik mempelajari kembali kegiatan belajar atau modul sebelumnya, maka penekanannya pada materi yang kurang dikuasai tersebut.

3) Pengelola

Pihak pengelola perlu membuat laporan penyelenggaraan tes yang telah dikerjakan oleh peserta didik dan jumlah peserta didik yang telah menyelesaikan tes, waktu dan tempat pelaksanaan tes, kendalakendala dalam penyelenggaraan, baik dari aspek teknis maupun non teknis. Laporan ini bermanfaat sekali terutama untuk laporan kemajuan proses maupun hasil belajar peserta didik.

\section{Hal-Hal yang Perlu Diperhatikan}

Hal-hal yang perlu diperhatikan berkaitan dengan pelaksanaan tes/ujian baik Tes Akhir Kegiatan (TAK), Tes Akhir Modul (TAM), Tes Akhir Unit (TAU), maupun Tes Akhir Semester (TAS) adalah:

a. Mengingat penyelenggaraan tes pada SMPT berbasis TIK dilakukan secara online, kemungkinan berkaitan dengan akses internet maupun listrik. Untuk mengatasi kendala tersebut, tes atau ujian dapat dilakukan secara offline dengan cara mengunduh (download) terlebih 
dahulu selanjutnya disimpan dalam server. Dengan demikian peserta didik tetap dapat mengikuti tes tanpa terhambat oleh akses internet.

b. Penyelenggaraan Tes Akhir Kegiatan, Tes Akhir Modul, Tes Akhir Unit, dan Tes Akhir Semester dapat diulang apabila peserta didik masih belum menguasai kompetensi yang diharapkan dengan syarat mereka telah mempelajari kembali kegiatan belajar atau modul yang belum mereka kuasai. Peserta didik diberi kesempatan untuk 2 kali mengulang. Apabila setelah dua kali mengulang belum berhasil, mereka wajib mempelajari materi yang belum dikuasai pada modul tersebut. Agar tidak mengulang tes, sebaiknya peserta didik terlebih dahulu mengerjakan soal-soal yang ada di menu latihan. Soal-soal dalam menu latihan ini hampir sama dengan soalsoal yang terdapat dalam tes, baik dari cakupan materi, bobot soal, maupun tingkat kesukaran soal.

c. Peserta didik dianggap belum berhasil mengerjakan Tes Akhir Kegiatan, dan Tes Akhir Modul apabila belum mencapai standar ketuntasan
75\%. Sedangkan tingkat ketuntasan pada Tes Akhir Unit, dan Tes Akhir Semester standar ketuntasan (SKBM) ditentukan oleh masingmasing perintisan SMP Terbuka.

d. Perlu ditekankan bahwa penilaian hasil belajar peserta didik tidak hanya bersumber pada hasil tes, tetapi juga dari non tes seperti tugas-tugas maupun latihan, karangan, dan karya ilmiah lainnya yang ditugaskan oleh Guru Bina. Diharapkan penilaian hasil belajar peserta didik akan mengacu pada portofolio peserta didik yang meliputi:

1) Kegiatan belajar yang telah diikuti oleh peserta didik,

2) Catatan peserta didik,

3) Kuis yang telah dikerjakan peserta didik,

4) Forum diskusi yang telah diikuti oleh peserta didik,

5) Tutorial yang telah diikuti oleh peserta didik,

6) Latihan dan tugas yang telah dikerjakan peserta didik,

7) Tes/ujian yang telah dikerjakan peserta didik,

Lebih jelasnya dapat dilihat pada Tabel 1 berikut.

Tabel 1. Komponen Penilaian Hasil Belajar Peserta didik

\begin{tabular}{|l|l|l|l|l|}
\hline No & \multicolumn{1}{|c|}{ Komponen } & $\begin{array}{c}\text { Frekuensi atau } \\
\text { Skor }\end{array}$ & Bobot & $\begin{array}{c}\text { Hasil Akhir (Frekuensi } \\
\text { atau Skor } x \text { Bobot) }\end{array}$ \\
\hline 1. & $\begin{array}{l}\text { Kegiatan belajar yang telah } \\
\text { dilkuti }\end{array}$ & Frekuensi: & & \\
\hline 2. & Catatan peserta didik & Frekuensi: & & \\
\hline 3. & Kuis & Frekuensi: & & \\
\hline 4. & Forum diskusi & Frekuensi: & & \\
\hline 5. & Tutorial & Frekuensi: & & \\
\hline 6. & Latihan & Skor: & & \\
\hline 7. & Tugas & Skor: & & \\
\hline 8. & Tes Akhir Kegiatan & Skor: & & \\
\hline 9. & Tes Akhir Modul & Skor: & & \\
\hline 10. & Tes Akhir Unit & Skor: & & \\
\hline 11. & Tes Akhir Semester & Skor: & & \\
\hline & \multicolumn{3}{l}{ Rata-rata } & \\
\hline
\end{tabular}




\section{PENUTUP}

\section{Simpulan}

Penilaian hasil belajar peserta didik SMP Terbuka yang menjadi perintis Pengembangan Program Pembelajaran Berbasis TIK terdiri atas:

a. Penilaian hasil belajar oleh diri peserta didik sendiri (SelfAssesment),

b. Penilaian hasil belajar oleh pendidik (Teacher Assesment),

c. Penilaian hasil belajar oleh satuan pendidikan (Institusional Assesment/ School Examination),

d. Penilaian hasil belajar oleh pemerintah (National Assessmentl National Examination).

Penilaian hasil belajar oleh peserta didik sendiri pada SMP Terbuka berbasis TIK lebih dikenal dengan Tes Akhir Kegiatan (TAK). Penilaian hasil belajar oleh pendidik dikenal dengan Tes Akhir Modul (TAM), Tes Akhir Unit (TAU) dan Tes Akhir Semester (TAS). Sedangkan penilaian hasil belajar oleh satuan pendidikan dikenal dengan ujian sekolah. Penilaian hasil belajar oleh pemerintah dikenal dengan ujian nasional.

Beberapa jenis penilaian hasil belajar peserta didik SMP Terbuka berbasis TIK dilakukan secara online, yaitu Tes Akhir Modul (TAM), Tes Akhir Unit (TAU), dan Tes Akhir Semester. Sementara untuk pelaksanaan ujian sekolah dan ujian nasional dilaksanakan secara manual mengikuti ujian yang ditempuh oleh peserta didik SMP reguler. Untuk mengikuti tes ini dapat diakses pada alamat: http://smpt.dit-plp.go.id

Dalam melakukan tes online diperlukan ketrampilan dalam menjalankan komputer. Oleh karena itu dituntut kemampuan komputer minimal tingkat dasar bagi para penggunanya. Di samping itu, ada beberapa tahapan yang harus diikuti dalam menjalankan tes online ini, mulai dari persiapan, pelaksanaan, sampai dengan tindak lanjut tes. Tahapan tersebut perlu diikuti agar dapat mengikuti tes online dengan lancar.

\section{Saran}

Beberapa saran yang dapat diajukan antara lain:

a. Mengingat penyelenggaraan tes SMPT berbasis TIK dilakukan secara online berkaitan dengan akses internet maupun listrik yang kemungkinan akan mengalami kendala dalam penyelenggaraannya. Mengatasi kendala tersebut, Guru Bina dengan dibantu oleh admin/ teknisi sekolah mengunduh (download) tes atau ujian sehingga dapat dilakukan secara offline. Dengan demikian peserta didik tetap dapat mengikuti tes tanpa terhambat oleh akses internet.

b. Guru Bina dapat menghubungi admin/teknisi sekolah apabila mengalami permasalahan berkaitan dengan perangkat komputer dan aplikasinya. Admin/teknisi sekolah dapat menghubungi Admin Direktorat PSMP apabila tidak dapat mengatasinya.

\section{DAFTAR PUSTAKA}

Direktorat PSMP. (2009). Naskah Akademik Pengembangan Program Pembelajaran Berbasis TIK Pada SMP Terbuka. Jakarta. . (2009). Grand Design Program Pembelajaran Berbasis TIK Pada SMP Terbuka. Jakarta. . (2009). Panduan Guru Bina Program Pembelajaran Berbasis TIK Pada SMP Terbuka. Jakarta. (2009). Petunjuk Untuk Peserta didik Program Pembelajaran Berbasis TIK Pada SMP Terbuka. Jakarta.

Mudjijo. (1995). Tes Hasil Belajar. Jakarta: Bumi Aksara.

Depdiknas. (2007) Permendiknas No. 20 Tahun 2007 tentang Standar Penilaian Pendidikan.

Thorndike, R.L. \& Hagen, H.P. (1977). Measurement and Evaluation in Psychology and Education. 4th.ed. New York: Harcout 
Brace Jovanovich Inc.

Website:

http://www.pgri1-dpk.net/

index.php?option=com_content\&view=ar.(2009).

Penyelenggaraan Tes Online

Website:

http://

ptinvosasystems.indonetwork.co.id/67162/

sistem-test-online.htm. (2009) Sistem Test

Online 